\title{
NFKB1 Gene Product
}

National Cancer Institute

\section{Source}

National Cancer Institute. NFKB1 Gene Product. NCI Thesaurus. Code C131126.

A protein encoded by the NFKB1 gene. 